Bartholomew, J. W. \& MitTwer, T. (1951). J. gen. Microbiol. 5, 39-45.

\title{
Cell Structure in Relation to the Gram Reaction as Shown During Lysis of Bacillus subtilis
}

\author{
By J. W. BARTHOLOMEW AND T. MITTWER \\ Department of Bacteriology, University of Southern California, Los Angeles, California
}

SUMMARY: The cell wall of Bacillus subtilis was shown to lie externally to the Gram-positive staining area of the cell. Conversion of these bacteria to the Gramnegative state, whether natural or induced, did not necessarily result in a decrease in cell size. When a decrease occurred it was correlated with the disappearance of an 'ectoplasm' staining area and with the inability of the residual cell substance to be converted to the Gram-positive state with magnesium ribonucleate.

Cell autolysis proceeded as follows. First the cell lost magnesium ribonucleate and was therefore Gram-negative, the ectoplasm and cell wall staining areas were retained, and the cell could be reconverted to the Gram-positive state by exposure to magnesium ribonucleate. The size of the cell was normal. Next, the ectoplasm and cell wall staining areas disappeared. This was correlated with an inability to be reconverted to the Gram-positive state and with a smaller size. Finally, cell autolysis was completed and the cell disappeared.

Gram-negative species were shown to possess an ectoplasm staining area which differed from that of normal Gram-positive cells since it could not be made to stain Gram-positive by exposure to magnesium ribonucleate. The ectoplasm staining area of Gram-positive cells was shown not to be in itself the reason for Gram-positive staining. However, the presence of this area correlated with the cells' ability to be reconverted to the Gram-positive state by magnesium ribonucleate, and thus it is probably important in the Gram reaction.

It has long been established that lytic procedures result in the conversion of Gram-positive bacteria to a Gram-negative state. This conversion has been shown to result from the action of autolytic enzymes within the dead or dying cell (Dubos, 1937; Jones, Stacey \& Webb, 1949), crystalline ribonuclease (Bartholomew \& Umbreit, 1944), bile (Henry \& Stacey, 1943), acids and alkalis (Deussen, 1920), and many other agents. The presence of Gram-negative forms in cultures of Gram-positive bacteria is thought to be due to the autolysis of the dead cells present (Dubos, 1937; Frazier \& Boyer, 1934). In a culture of Bacillus subtilis, the cells which stain Gram-negatively are frequently observed to be smaller than those which stain Gram-positively. This observation has never been adequately explained. Some have interpreted the larger size of the Gram-positive organisms as being caused by the dye-iodine complex adhering to the outside of the cells. Others have interpreted this as an outer Grampositive layer, and an inner Gram-negative layer, the outer layer having been lost by the Gram-negative forms (Gutstein, 1924, 1925; Eisenberg, 1909; Churchman, 1927, 1929).

Gutstein $(1924,1925)$ and Eisenberg (1909) claimed to have stained an ectoplasm layer in bacterial cells, which may be the same as the Gram-positive cortex of Churchman (1927). The work of Gutstein and of Eisenberg can be easily reproduced, and an outer protoplasm layer is stained by these methods. 
A definite area exterior to the protoplasm can be stained by any one of the many cell-wall stains which have been published (Dyar, 1947; Knaysi, 1941; Welshimer \& Robinow, 1949). As far as the present authors are aware, no attempt has been made to correlate the conversion of a Gram-positive cell to the Gram-negative state (sometimes producing cells which appear much smaller) with the state of the cell wall and ectoplasm staining areas.

The following paper reports the results of experiments designed to follow staining changes occurring in the cell wall and ectoplasm staining areas during the conversion of $\boldsymbol{B}$. subtilis cells into a Gram-negative state.

\section{MATERIALS AND METHODS}

Our method consisted of staining cells by Gram stain and by special stains for cell wall, ectoplasm, etc. Wherever possible, the various staining methods were applied in succession to a single heat-fixed bacteriological slide and the results recorded by photo-micrography after each stain used. It was usually possible to follow one bacteriological field through several different staining methods.

Organism. The cells from a $\mathbf{1 2} \mathrm{hr}$. nutrient agar slant of $\boldsymbol{B}$. subtilis grown at $25^{\circ}$ were suspended in distilled water and several hundred thin smears were made. All slides were heat fixed.

Gram stain. Hucker \& Conn's (1923) modification was used throughout. Measurements were also made using the Kopeloff \& Beerman (1922) modification for purposes of comparison and no differences were found between the size of the cells stained by the two methods.

Cell wall stain. Dyar's (1947) cell wall stain was used. Three drops of $0 \cdot 34 \%$ cetyl pyridinium chloride were applied to the smear and 1 drop of saturated aqueous Congo red was mixed with this on the slide. The slide was then washed in water and dried.

'Ectoplasm' stain (see Discussion). The Gutstein (1924) modification of Eisenberg's (1909) method was used. Gutstein stated that this procedure stained the 'membrane and external part of the cytoplasm'. The smears were mordanted with $5 \%$ aqueous tannic acid for 5 min., and then stained with $1 \%$ aqueous malachite green for 1 min. There can be no doubt that this procedure stains an area, interior to the cell wall area, which appears as a deeply stained ring around the inner area of the protoplasm. The exact nature of this stained area has never been determined. In this paper we are interested in it simply as an area which can be differentiated by staining methods.

Ribonuclease digestion. The method of Bartholomew \& Umbreit (1944) was used. Cells were suspended in distilled water and autoclaved. Crystalline ribonuclease solution (4 mg./100 ml. distilled water) was combined in equal volume with the autoclaved cell suspension and the mixture incubated in a water-bath at $45^{\circ}$ for $1 \mathrm{hr}$.

Bile digestion. This digestion was conducted as outlined by Henry \& Stacey (1943). Cells were placed in $2 \%$ bile and held at $60^{\circ}$ overnight or longer.

Replating. The method of replating used was that of Henry \& Stacey (1943). The enzyme-digested cells (Gram-negative cytoskeletons) were washed by centrifugation in distilled water, resuspended in $1 \%$ magnesium ribonucleate 
plus $\mathbf{0} \cdot \mathbf{1} \%$ formaldehyde for $5 \mathrm{~min}$., and then smeared on slides. Most of these cells were then Gram-negative.

Photographs. All photographs were taken with a Bausch \& Lomb apochromatic objective $90 \times$, N.A. 1·30, and a $20 \times$ eyepiece. The pictures were enlarged to $3600 \times$ for reproduction here.

Measurements. Heat-fixed cells were used for all measurements. Cell widths were measured with a calibrated filar micrometer and by direct measurements of enlarged photographs. The filar measurements represent the average of fifty to eighty cells and the photographic measurements are the average of all cells appearing in a single photograph (usually twelve to twenty-five cells).

General. Cells treated in various manners were stained, measured, and photographed; untreated slides were stained by Gram's method and suitable fields where Gram-negative cells occurred photographed. In cases where a series of photographs were made of the same field, the smear was decolorized between stains with ethanol or acetone, restained, and photographed again. It was found to be immaterial whether the Gram stain was applied before the cell wall stain, or vice versa, with or without an intervening stain with a single dye, as the morphology and size were not changed. However, after the ectoplasm stain was performed, no further restaining could be done as the mordanting process caused a permanent change in the cells.

\section{RESULTS}

Our first experiments were conducted to convince ourselves of the validity of Dyar's cell wall stain. In plasmolysed cells of $\boldsymbol{B}$. cereus the cell wall remained intact with the cytoplasm visibly shrunk away from it. There can be no doubt that Dyar's procedure stains a structure exterior to the protoplasm, and that this structure is at least in part the cell wall. The relationship of the capsule to this staining procedure has never been convincingly shown, but this point is not important as far as the following experiments are concerned.

Dyar's cell wall stain was compared to the Knaysi (1941) stain and similar results were obtained. Welshimer \& Robinow (1949) had previously compared their stain with that of Dyar, and found it to be similar. Therefore the Dyar stain is comparable to other well-known cell wall stains.

Next, an extensive series of cell measurements was made. Comparisons were made between widths of cells stained by the various procedures used, and of cells in various stages of conversion from Gram-positive to Gram-negative. The results are presented in Table 1.

Figs. 1-4 of Pl. 1 can also be used in interpreting these data. In these figures cell 1 is a small Gram-negative cell, cell 2 is a partially converted Grampositive cell, and cells 3-5 are normal Gram-positive cells. Fig. 1 represents a Gram-stained smear. Figs. 2-4 represent the same field stained respectively with crystal violet, Dyar's cell wall method, and with Gutstein's ectoplasm stain. Much of the following can be verified by applying calipers to the photographs.

The Gram-positive cells average $0 \cdot 87 \mu$. in width, while the width between the inner areas of the cell wall stained material was $0 \cdot 71 \mu$. A visual comparison of 
Table 1. Average cell measurements as determined by filar micrometer (fifty to eighty cells) and photomicrographically (at least twenty cells)

\begin{tabular}{|c|c|c|}
\hline & \multicolumn{2}{|c|}{ Measurement $(\mu)}$. \\
\hline & Photomicrographic & Filar \\
\hline Crystal violet alone, total width & 0.90 & 0.98 \\
\hline Safranin alone, total width & 0.74 & 0.72 \\
\hline Acid fuchsin, total width & 0.74 & - \\
\hline Crystal violet and iodine, total width & 0.92 & $1 \cdot 04$ \\
\hline Gram-stained, Gram-positive form & 0.87 & 0.83 \\
\hline Gram-stained, small Gram-negative form & $0 \cdot 37$ & - \\
\hline Gram-stained, large Gram-negative form & 0.87 & - \\
\hline $\begin{array}{l}\text { Gram-stained, ribonuclease-produced Gram- } \\
\text { negative forms }\end{array}$ & 0.75 & $0 \cdot 76$ \\
\hline $\begin{array}{l}\text { Enzyme-produced Gram-negative forms, restored to } \\
\text { Gram-positive state with magnesium ribonucleate } \\
\text { (digested with cryst. ribonuclease) }\end{array}$ & $0 \cdot 85$ & $\mathbf{0} \cdot \mathbf{8 6}$ \\
\hline Cell wall stain (Dyar's). Total outside width & $1 \cdot 29$ & $\mathbf{1} \cdot \mathbf{1 4}$ \\
\hline $\begin{array}{l}\text { Cell wall stain (Dyar's). Width between inner cell } \\
\text { wall limits }\end{array}$ & 0.71 & - \\
\hline Ectoplasm stain. Total outside width & 0.81 & $0 \cdot 80$ \\
\hline $\begin{array}{l}\text { Ectoplasm stain. Width between inner ectoplasm } \\
\text { limits }\end{array}$ & $0 \cdot 44$ & - \\
\hline
\end{tabular}

figs. 1 and 3 shows that the Gram-positive cells fit within the cell-wall area. It is obvious that the larger size of the Gram-positive cells is not due to a dyeiodine precipitate on the outside of the cell and the Gram-positive material must lie within the cell-wall area. It is also obvious that Gutstein's ectoplasm staining procedure stains an area mostly within the cell wall, and corresponding to approximately the outer half of the protoplasm material. In this, and many other strains studied, the Gram-negative cells seemed to be of two types. Some were small and.averaged $0 \cdot 37 \mu$., most were large and averaged $0 \cdot 87 \mu$. Some intermediates were observed. Cells converted to the Gram-negative state by the action of crystalline ribonuclease were nearly the same width as normal cells, unless the digestion was continued over a prolonged period of time. The normal-sized Gram-negative cells were still of normal width when replated with magnesium ribonucleate. The obviously small Gram-negative forms could not be replated with magnesium ribonucleate. The small difference in size between the crystal violet stained cells and those stained with safranin and acid fuchsin is probably without significance.

An extensive study was made of the correlation of Gram-positive to Gramnegative conversion with the appearance of the areas stained by the cell wall and ectoplasm staining methods. Although a large number of pictures were taken, the essential results can be represented by figs. 1-12 of Pls. 1 and 2 . The Gram-negative cells shown in these pictures were all the result of natural autolysis in a culture. Cells 1-5 in figs. 1-4 show the following points: cell 1 is a small Gram-negative cell in a chain of Gram-positive cells. It no longer is differentially stained by either the cell wall or ectoplasm methods, and it is distinctly smaller in size than the other cells shown. Although the cell wall is not clearly stained, as in the other cells, this staining procedure does result in 
a wider cell than when the Gram stain was used. Cell 2 is weakly Grampositive and has lost some of its ectoplasm staining material and cell wall staining material. The rest of the cells in the field are normal.

Many observers of a cell wall and ectoplasm stain preparation report that to them the stains appear to be staining similar structures. A glance at the adjacent ends of cells 4 and 5 as seen in figs. 3 and 4, shows clearly that different structures are stained by these two methods.

The Gram-negative cell marked with the arrow in figs. 5-8 (Pl. 1) shows that a cell may stain Gram-negatively and yet retain the ectoplasm and cell wall staining material. This cell appears the same in width as the normal Grampositive cells. The cell marked in figs. 9-12 (Pl. 2) shows a Gram-negative cell that still possesses cell wall staining material, but it does not possess ectoplasm staining material. The loss of this ectoplasm staining material has resulted in a cell which is visually smaller than the other cells, when stained by safranin, crystal violet, or the ectoplasm stain. Reduction in apparent size would then seem to correlate with the presence or absence of ectoplasm staining material.

Although the above experiments were conducted on naturally occurring autolysed cells, similar results were obtained in experiments using crystalline ribonuclease and bile. On conversion to the Gram-negative state with ribonuclease the ectoplasm and cell wall staining areas were still present, and could be restored to the Gram-positive state with magnesium ribonucleate. The cell wall and ectoplasm staining areas remained demonstrable unless the enzyme digestion was greatly prolonged, in which case factors other than the action of ribonuclease were responsible for the final disintegration of the cell. Bile was also used, with the same results except that it destroyed the ectoplasm and cell wall staining areas much more rapidly than the other methods studied.

Figs. 13 and $14(\mathrm{Pl} .2)$ are presented to show that Gram-negative cells also have ectoplasm staining areas. This is in agreement with the earlier reports of Eisenberg (1909).

\section{DISCUSSION}

In this paper the word 'ectoplasm' has been used to indicate the area stained by Gutstein's 'ectoplasm' stain. Unfortunately the nature of this area is not known, and this has resulted in much confusion as to the meaning of this word when applied to bacterial cells. It is an area which is chemically differentiated by the staining method used, but the reason for this differentiation is unknown.

Churchman $(1927,1929)$ has explained the small size of the Gram-negative cells in a culture of Gram-positive bacteria on a morphological basis. He claimed that all Gram-positive bacteria consisted of a Gram-negative medulla and a Gram-positive cortex which was lost on conversion to the Gram-negative state and which resulted in a smaller cell since only the Gram-negative medulla remained. The present work does not necessarily confirm the concepts of Churchman. In the first place, the areas differentiated might simply be chemical layers and not actual morphological structures as claimed by Churchman. Secondly, we have shown that cells may be Gram-negative and still be of their original size, and this would be impossible by Churchman's concepts. Thirdly, we have not shown that the material left in a small Gram-negative cell 
(Churchman's medulla) is actually Gram-negative in an intact and normal cell. The autolytic procedures by which the small Gram-negative stages were obtained, would also have had a considerable effect on the residual material.

It is apparent that if magnesium ribonucleate cannot be replaced on to the small Gram-negative forms, then the ectoplasm staining substance might well be necessary for magnesium ribonucleate to produce the Gram-positive state. If so, then this would mean that the essential Gram-positive materials must be located in the outer layers of the protoplasm. However, the ectoplasm staining material is not in itself responsible for the Gram-positive complex. This is indicated by its presence in Gram-negative cells and by the fact that Grampositive cells converted to the Gram-negative state may still possess ectoplasm staining material.

Our explanation of the results presented in this paper is as follows. The cell wall is not stained by any of the usual staining procedures including the Gram stain, and it has been shown that the Gram-positive staining material lies interior to the cell wall material. The protoplasm can be differentiated into two layers by the method of Gutstein. On conversion of a Gram-positive cell to Gram-negative by autolytic or enzyme digestion, the first step is the release of magnesium ribonucleate (Bartholomew \& Umbreit, 1944; Dubos, 1937; Henry \& Stacey, 1943; Jones, Stacey \& Webb, 1949). The cell now stains Gram-negatively and has intact all areas stained by the cell wall, ectoplasm, and ordinary staining methods. Magnesium ribonucleate can be recombined with the cell at this stage, and the now Gram-positive cell still has a normal width. Further digestive action destroys the ectoplasm and cell wall staining areas, the cell can no longer be reconverted to the Gram-positive state, and it is considerably smaller than the normal cell. Failure of the residual material to take the magnesium ribonucleate and hence stain Gram-positively, indicates that the ectoplasm staining layer plays an important role in the Gram-positive property. Finally, the process of autolysis or digestion may be completed and the cell may disappear. It is not clear whether the failure of the cell wall to stain at this later stage was due to its absence, or simply to a change in its chemical characteristics.

The ectoplasm staining area of normal Gram-negative bacteria deserves additional comment. This material must be considerably different from that in Gram-positive cells because the former is incapable of uniting with magnesium ribonucleate to produce the Gram-positive state (Bartholomew, 1946). This difference may well be due to the types of protein present in this area, and this difference may be that observed by Henry, Stacey \& Teece (1945).

The work presented in this paper was made possible by a generous grant from the Biological Stain Commission and from the Office of Naval Research. The authors wish to express their appreciation of the advice and assistance of Dr H. J. Conn.

\section{REFERENCES}

Bartholomew, J. W. (1946). Gram-positive characteristics of the Neisseria. J. Bact. $51,584$.

Bartholomew, J. W. \& Umbreit, W. W. (1944). Ribonucleic acid and the Gram stain. J. Bact. 48, 567 . 
Journal of General Microbiology, Vol. 5, No. 1

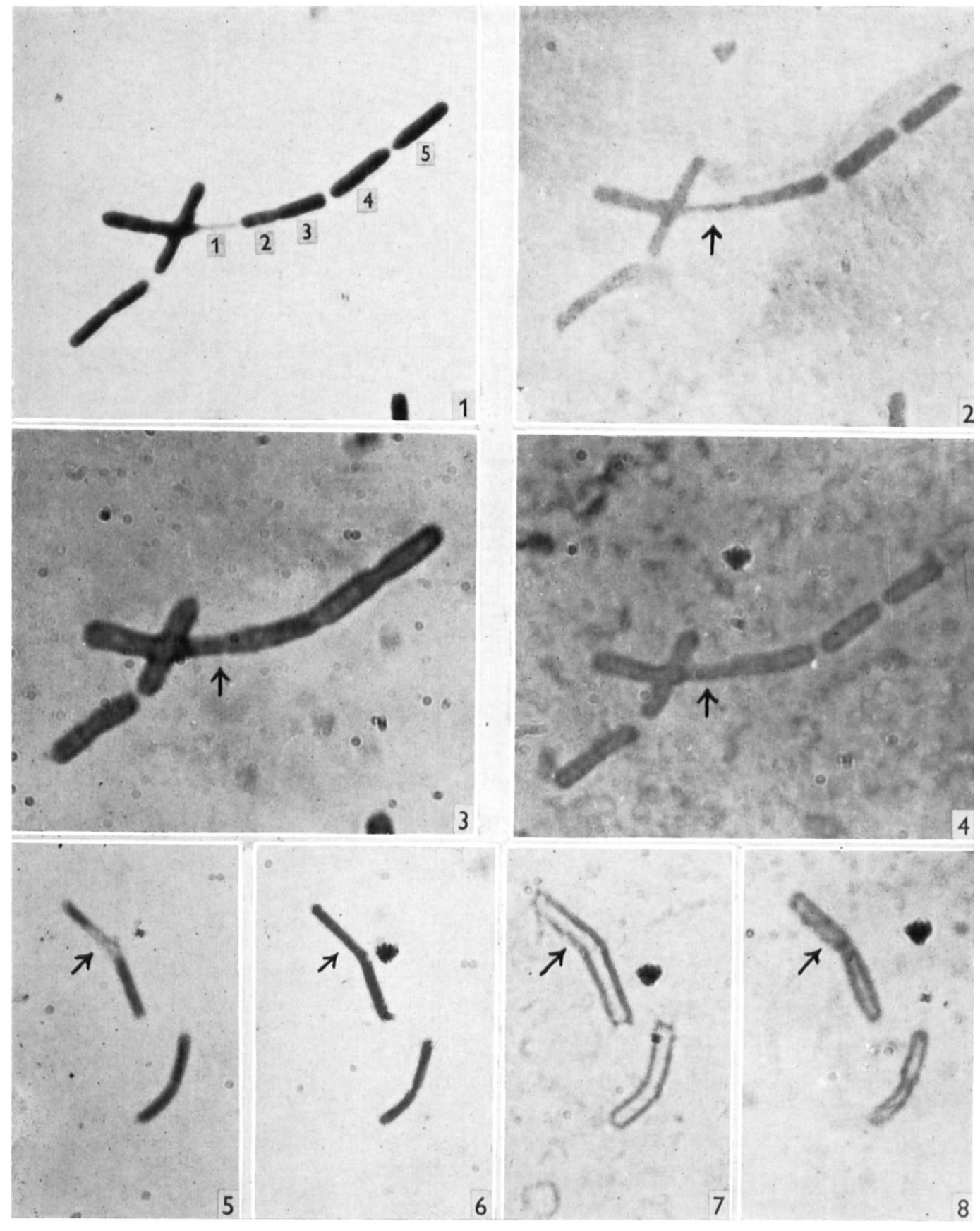

Figs. 1-8

J. W. Bartholomew and T. Mittwer-Cell structure in relation to Gram reaction. Plate I 
Journal of General Microbiology, Vol. 5, No. 1
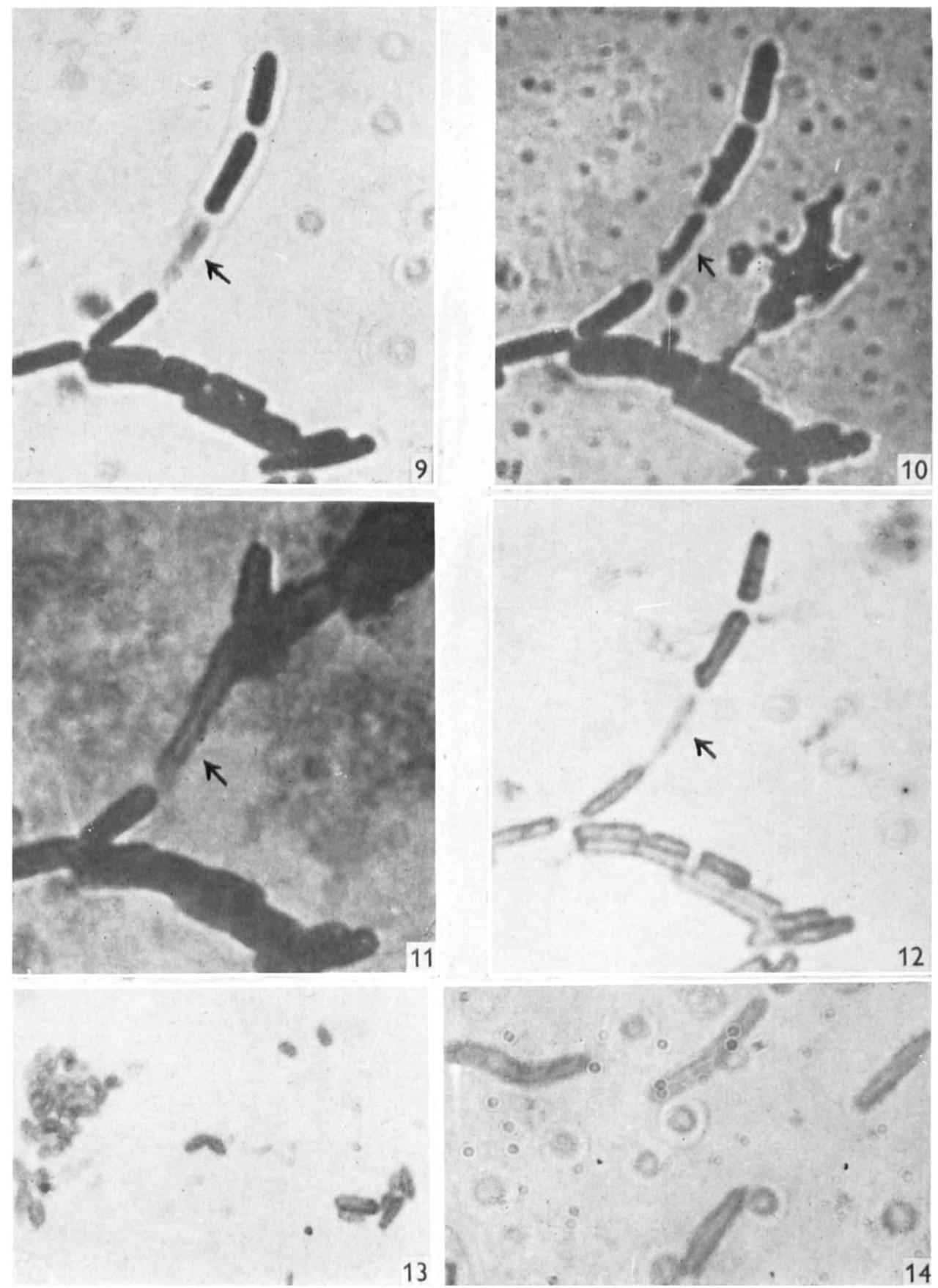

Figs. 9-14

J. W. Bartiolomew and T. Mittwer-Cell structure in relation to Gram reaction. Plate 2 
Churchman, J. W. (1927). The structure of B. anthracis and reversal of the Gram reaction. J. exp. Med. 46, 1007.

Churchman, J. W. (1929). Gram structure of cocci. J. Bact. 18, 413.

Deussen, E. (1920). Die Gramsche Bakterienfärbung, ihr Wesen und ihre Bedeutung. Biochem. Z. 103, 123.

Dubos, R. J. (1937). The autolytic system of pneumococci. J. exp. Med. 65, 873.

Dyar, M. T. (1947). A cell wall stain employing a cationic surface-active agent as a mordant. J. Bact. 53, 498.

Eisenberg, P. (1909). Studien zur Ektoplasmatheorie. II. Teil. Ueber das Ektoplasma und seine Veränderungen im infizierten Tier. Zbl. Bakt. (1. Abt. Orig.), 49, 465 .

Frazier, W. C. \& Boyer, A. J. (1934). A method for distinguishing living from dead cells of Gram-positive bacteria by stained preparations. J. Bact. 27, 31 .

Gutstein, M. (1924). Das Ektoplasma der Bakterien. I. Ueber eine allgemeine Methode zur Darstellung des Ektoplasmas der Grampositiven Bakterien. Z Zbl. Bakt. (1. Abt. Orig.), 93, 393.

Gutsteın, M. (1925). Das Ektoplasma der Bakterien. II. Mitt. Ueber färberische Verscheidenheiten zwischen Grampositiven und Gramnegativen Bakterien. Ein Beitrag zur Theorie der Gramschen Färbung. Zbl. Bakt. (1. Abt. Orig.), 94, 145.

Henry, H. \& Stacey, M. (1943). Histochemistry of the Gram-staining reaction for micro-organisms. Nature, Lond., 151, 671.

Henry, H., Stacey, M. \& Teece, E. G. (1945). Nature of the Gram-positive complex in micro-organisms. Nature, Lond., 156, 720.

Hucker, G. J. \& ConN, H. J. (1923). Methods of Gram staining. Tech. Bull. N.Y. (St.) agric. Exp. Sta. 93, 1.

Jones, A. S., Stacey, M. \& Webb, M. (1949). Studies on the autolytic systems of Gram-positive micro-organisms. I. The lytic system of staphylococci. Biochim. Biophys. Acta, 3, 383.

KNAYSI, G. (1941). Observations on the cell division of some yeasts and bacteria. J. Bact. 41, 141.

Kopeloff, N. \& Beerman, P. (1922). Modified Gram stains. J. infect. Dis. 31, 480.

Welshimer, H. J. \& Robinow, C. F. (1949). The lysis of Bacillus megatherium by lysozyme. J. Bact. 57, 489.

\section{EXPLANATION OF PLATES}

All figures represent a magnification of $\times 3600$.

Plate 1

Figs. 1 and 5. Bacillus subtilis, Gram stain.

Figs. 2 and 6. Same fields, stained with crystal violet only.

Figs. 3 and 7. Same fields, stained with Dyar's cell wall stain.

Figs. 4 and 8. Same fields, stained with Gutstein's ectoplasm stain.

Plate 2

Fig. 9. Bacillus subtilis, Gram stain.

Fig. 10. Same field, stained with crystal violet only.

Fig. 11. Same field, stained with Dyar's cell wall stain.

Fig. 12. Same field, stained with Gutstein's ectoplasm stain.

Fig. 13. Pseudomonas putida, stained with Gutstein's ectoplasm stain.

Fig. 14. Spirillum sp. stained with Gutstein's ectoplasm stain.

(Received 20 March 1950) 